\title{
ВИВЧЕННЯ ТРИВОЖНО-ДЕПРЕСИВНИХ РОЗЛАДІВ ТА ОЦІНКА ЯКОСТІ ЖИТТЯ У ХВОРИХ НА ТИРЕОПАТІЮ
}

\author{
І. П. Савченко, М. В. Степова, Л. М. Мазур \\ ДВНЗ «Тернопільський державний медичний університет \\ імені І. Я. Горбачевського МОЗ Украӥни» \\ ННІ медсестринства
}

Хвороба має значний вплив на фізичне здоров’я, емоційні реакції та поведінку людини. У статті досліджено зв’язок між психоемоційним станом пацієнта із патологією щитоподібної залози та оцінкою якості життя. Психічні та поведінкові розлади надзвичайно поширені й уражають 25 \% людей в різні періоди їх життя, мають економічний вплив на суспільство і на якість життя окремих осіб 3 психічними розладами.

\section{STUDY OF THE ANXIETY-DEPRESSIVE DISORDERS AND ASSESSMENT OF THE QUALITY OF LIFE IN PATIENTS WITH THYROPATHY}

\author{
I. P. Savchenko, M. V. Stepova, L. M. Mazur \\ I. Horbachevsky Ternopil State Medical University \\ Institute of Nursing
}

\begin{abstract}
The disease has a considerable impact on physical health, emotional reactions and behavior of the person. The article deals with the connection between psycho-emotional state of a patient with thyroid gland disorder and the assessment of quality of life. Mental and behavioral disorders are extremely widespread and appear in $25 \%$ of people in different periods of their life, making economical influence on the society and on the quality of life in individuals with mental disorders.
\end{abstract}

Вступ. Протягом кількох десятків років негативні наслідки зростання урбанізації, погіршення соціально-економічного розвитку країни, зниження якості життя та бідність населення призвело до зростання депресивних та тривожних розладів. На жаль, статистика нас переконує, що депресія - достатньо широко розповсюджене захворювання.

За даними Американської психіатричної асоціації (АПА), 2-5 \% населення планети страждають від депресії в різні періоди свого життя, 22-23 \% серед контингенту, що спостерігається у загальній медичній практиці. Щорічно на клінічно розпізнану депресію хворіють не менше 200 млн людей, така цифра постійно зростає. Відповідно до прогнозів АПА, до 2020 р. депресія може посісти перше місце серед захворювань у світі, що випередить сьогоднішніх лідерів - серцевосудинних та інфекційних захворювань. Проблема посилюється тому, що більшість депресивних станів

(ㄱ І. П. Савченко, М. В. Степова, Л. М. Мазур, 2019 не розпізнають, оскільки вони дуже часто маскуються під соматовегетативними симптомами [1, 2].

Афективні розлади поширені й серед хворих на патологію щитоподібної залози, але, на жаль, мало хто замислюється над тим, що порушення нервової системи можуть бути не причиною, а наслідком дисфункції внутрішніх органів, а саме - щитоподібної залози (ЩЗ). Взаємозв'язок стресу, тривоги та депресії значно погіршує перебіг захворювання щЗ, що призводить до зниження працездатності, збільшення частоти звернення за медичною допомогою, а також зниження якості життя пацієнта [3].

За визначенням ВОО3: «Якість життя - це сприйняття людиною своєї позиції у житті, у тому числі фізичного, психічного та соціального благополуччя, залежно від якості середовища, в якому вона живе, а також ступеня задоволення конкретним рівнем життя та іншими складовими психологічного комфорту». Саме тому показник якості життя можна вважати 
індикатором впливу захворювання на людину, що в подальшому дає можливість зрозуміти ії потреби та можливі шляхи реабілітації [4].

Мета роботи - вивчити особливості психологічного статусу та якості життя пацієнтів із гіпо- та гіперфункцією щитоподібної залози.

Основна частина. Порушення функції ЩЗ, як правило, супроводжується психоневрологічними змінами [5]. Частота виникнення цих змін пов'язана з порушенням секреції тиреоїдних гормонів, що патологічно впливає на гіпоталамус і кору головного мозку, оскільки гормони щЗ у фізіологічних дозах стимулюють синтез внутрішньоклітинних білків нервової системи. Одним із найпоширеніших проявів психоневрологічних змін є астенічний синдром - сукупність підвищеної втоми з емоційною лабільністю, порушенням сну та вегетативними симптомами. При емоційній нестабільності пацієнти скаржаться на сповільнення процесів мислення, дратівливість, гнів, збудження, плаксивість, порушення сну (тривожні сновидіння, раннє пробудження, відсутність відчуття відпочинку після сну), в результаті чого виникає постійна втома $[6,7]$.

Під час лікування пацієнтів із проявами тривоги та депресії важливим аспектом у роботі медичної сестри $\epsilon$ забезпечення у лікарнях охоронного режиму, що передбачає спокійну атмосферу для мінімального подразнення психіки хворого, достатнього і міцного сну для повноцінного відпочинку. Велике значення має і психотерапевтична бесіда медичної сестри 3 пацієнтом із метою зменшення хворобливих відчуттів і переживань [8].

У дослідження було включено осіб лише жіночої статі віком 27-69 років, з них: 24 хворі на дифузний токсичний зоб (1 група), 20 хворих на гіпотиреоз
(2 група), які перебували на стаціонарному лікуванні в ендокринологічному відділенні Тернопільської університетської лікарні, та 15 практично здорових осіб жіночої статі, працівників медичних установ м. Тернопіоля, які в анамнезі не мали захворювання щ3 (3 група).

Діагностику коморбідних тривожних і депресивних розладів проводили з використанням госпітальної шкали тривоги та депресії (HADS).

Шкала запропонована A. S. Zigmond та R. P. Snaith y 1983 р. і включає 14 тверджень, з яких 7 відповідають тривожним розладам і 7 - депресивним, що підраховують окремо. Анкету-опитувальник заповнювали безпосередньо самі пацієнти або методом інтерв'ю. Результат 0-7 балів свідчить про відсутність симптомів тривоги та депресії, 8-10 балів - про субклінічно виражену тривогу/депресію, 11 балів і вище - про клінічно виражену тривогу/депресію.

За результатами дослідження встановлено, що найбільш вираженим показником «психічного нездоров'я» був рівень клінічної тривоги, виявлений у 15 (62,5 \%) пацієнтів 1 групи, у 10 (50 \%) 2 групи. Також було виявлено високий рівень субклінічної депресії у 12 (50 \%) пацієнтів 1 групи, що значно перевищує показники 2 та 3 груп. Таким чином, порівнюючи показники усіх груп, можна стверджувати, що прояви тривоги характерні для пацієнтів із гіпо- та гіперфункцією ЩЗ, натомість прояви депресії було виявлено лише в осіб із дифузним токсичним зобом (табл. 1). Такі результати підтверджують літературні дані про те, що наявність тривоги та депресії у пацієнтів із дифузним токсичним зобом (ДТз) пов'язані $з$ токсичною дією тиреоїдних гормонів на центральну нервову систему [6].

Таблиця 1. Рівень тривоги та депресії у пацієнтів досліджуваних груп

\begin{tabular}{|l|c|c|c|}
\hline \multicolumn{1}{|c|}{ Показник } & $\begin{array}{c}1 \text { група } \\
\mathrm{n}=24(\%)\end{array}$ & $\begin{array}{c}2 \text { група } \\
\mathrm{n}=20(\%)\end{array}$ & $\begin{array}{c}3 \text { група } \\
\mathrm{n}=15(\%)\end{array}$ \\
\hline Тривога відсутня & 12,5 & 20 & 60 \\
\hline Субклінічний рівень тривоги & 25 & 30 & 13,4 \\
\hline Клінічний рівень тривоги & 62,5 & 50 & 26,6 \\
\hline Депресія відсутня & 12,5 & 60 & 73,4 \\
\hline Субклінічний рівень депресії & 50 & 10 & 20 \\
\hline Клінічний рівень депресії & 37,5 & 30 & 6,6 \\
\hline
\end{tabular}

Якість життя характеризує загальний добробут та ступінь задоволеності тими ланками життя, на які впливає стан здоров'я, та навпаки - захворювання змінює біосоціальний статус, що відображається на оцінці якості життя [4]. Для оцінки якості життя використовували шкалу О. С. Чабана, О. О. Хаустової, що містить 10 запитань, які включають інтегровані показники задоволення фізичним станом, сімейним добробутом, соціальним статусом, трудовою діяльністю, самопочуттям у цілому. Мінімальна кількість балів - 0, максимальна - 100. Результат до 56 балів включно - дуже низький рівень якості життя, 
57-66 включно - низький, 67-75 - середній, 76-82 високий, від 83 балів - дуже високий.

Відповідно до проведених нами досліджень, більшість - 37,5 \% (9 осіб з дТ3) та 40 \% (8 з гіпотиреозом) відзначила низький рівень, 33,5 \% (8 з дТ3) і 25 \% (5 з гіпотиреозом) стверджує про дуже низький рівень якості життя (табл. 2). Дослідження показали, що пацієнти, які мають патологію щитоподібної залози - незадоволені рівнем якості життя (ЯЖ). Це підтверджує те, що ЯЖ - це рівень благополуччя і задоволення тими сторонами, на які впливає хвороба чи процес їі лікування [9].

Таблиця 2. Рівень якості життя у обстежених пацієнтів із патологією щитоподібної залози та здорових осіб

\begin{tabular}{|l|c|c|c|}
\hline \multicolumn{1}{|c|}{ Рівень якості життя } & $\begin{array}{c}1 \text { група } \\
\mathrm{n}=24(\%)\end{array}$ & $\begin{array}{c}2 \text { група } \\
\mathrm{n}=20(\%)\end{array}$ & $\begin{array}{c}3 \text { група } \\
\mathrm{n}=15(\%)\end{array}$ \\
\hline Дуже високий & - & - & 20 \\
\hline Високий & 8,3 & 15 & 26,7 \\
\hline Середній & 20,7 & 20 & 33,3 \\
\hline Низький & 37,5 & 40 & 13,4 \\
\hline Дуже низький & 33,5 & 25 & 6,6 \\
\hline
\end{tabular}

Таким чином, патологія щитоподібної залози може істотно впливати не тільки на фізичний стан, а й на психологію, емоційні реакції, поведінку людини, що, у свою чергу, може призвести до подальшої дезадаптації у суспільному житті. Оцінка якості життя $\epsilon$ невід'ємною частиною комплексного аналізу нових методів діагностик, лікування, профілактики та надання медичної допомоги й тому потребує створення усіх передумов для практичного застосування у вітчизняних реаліях [9].

Висновки. Виникнення тривожно-депресивних розладів $\epsilon$ характерним для пацієнтів із захворюваннями щитоподібної залози. У пацієнтів із дифузним токсичним зобом високий рівень займає клінічна три-

\section{СПИСОК ЛІТЕРАТУРИ}

1. Юнак В. Ю. Депрессия : учебник / В. Ю. Юнак. - К. : Здоров'я, 2012. - С. 6-16.

2. Передерій В. Г. Основи внутрішньої медицини. Том 2 : підручник [для студ. вищ. мед. навч. закл.] / В. Г. Передерій, С. М. Ткач. - Вінниця : Нова Книга, 2009. -93 c.

3. Усіченко І. Г. Основи догляду в домашніх умовах : навч. посіб. / І. Г. Усіченко, А. В. Царенко, С. А. Місяк. Тернопіль : Укрмедкнига, 2000. - 262 с.

4. Корнацький В. М. Вплив тривоги та депресії на якість життя пацієнтів із серцево-судинною патологією / В. М. Корнацький, Д. М. Мороз // Буковинський медичний вісник. - 2015. - № 4. - С. 84-85.

5. Калинин А. П. Неврологические расстройства при эндокринных заболеваниях : руководство для врачей / А. П. Калинин, С. В. Котов, И. Г. Рудакова. - 2-е изд., пере- вога (62,5 \%) та субклінічна депресія (50 \%), натомість у хворих на гіпотиреоз було виявлено лише клінічну тривогу (50 \%). Це свідчить про те, що пацієнти з гіперфункцією щитоподібної залози більш схильні до виникнення психоневрологічних змін через токсичний вплив тиреоїдних гормонів на центральну нервову систему. У пацієнтів із тиреопатією, на противагу здоровим особам із 3 групи порівняння, найчастіше при опитуванні виявляється низький та дуже низький рівень якості життя.

Оцінка рівня тривожно-депресивних розладів та їх впливу на якість життя дає змогу правильно оцінити стан пацієнта, що в подальшому допомагає планувати профілактичні, лікувальні та реабілітаційні заходи.

раб. и дополн. - М. : ООО «Медицинское информационное агентство», 2009. - 488 с.

6. Особенности психоэмоционального статуса пациентов с патологией щитовидной железы / Ю. В. Синицына, С. М. Котова, В. А. Точилов, Ф.К. Хетагурова // Российский семейный врач. - 2014. - Т. 3, № 18. - 36 с.

7. Ендокринологія: підручник [для студ. вищих мед. навч. закл.] / П. М. Бондар, Г. П. Михальчишин, Ю. І. Комісаренко та ін. - 4-те вид., оновлене та доповнене. - Вінниця : Нова Книга, 2017. - 93 с.

8. Чабан О. С. Основи загальної і медичної психології : підручник / О. С. Чабан, І. С. Вітенко. - Тернопіль : Укрмедкнига, 2003. - С. 257-282.

9. Якість життя людини: сутність поняття / Н. М. Третяк, О. В. Басова, Н. В. Горяінова [та ін.] // Гематологія і переливання крові. - 2014. - Вип. 37. - С. 241-242. 